\title{
Arbor
}

\section{Teatro y narratividad}

\author{
José Luis García Barrientos
}

Arbor CLXXVII, 699-700 (Marzo-Abril 2004), 509-524 pp.

La oposición entre teatro y narratividad cuenta con una base sólida, bien fundada, y se perfila con la máxima pureza y claridad en el nivel de abstracción que representan los dos -y sólo dos- modos de imitación que distinguió Aristóteles en su Poética: el de la narración y el de la actuación o el drama. Aunque son evidentes -pero en planos de mayor concreción, de los "géneros», más o menos históricos, a las obras particulares-las contaminaciones e interferencias entre ellos, y uno de los caminos más transitados de la dramaturgia contemporánea, desde finales del siglo XIX hasta hoy, ha sido el de una persistente y quizás progresiva narrativización, en el que se hacen algunas calas, la oposición entre las dos modalidades de la ficción, lejos de neutralizarse, se mantiene a juicio del autor intacta y las fronteras entre una y otra no resultan oscuras ni confusas, sino particularmente nítidas.

\section{Planteamiento}

$\mathrm{Al}$ abordar la relación entre teatro y narratividad, lo primero que llama la atención y lo que incita más a la reflexión teórica es quizás que se trata de una relación paradójica, lo que no es en absoluto lo mismo que oscura o confusa; al contrario, sus perfiles me parecen particularmente nítidos, como intentaré poner de relieve en este ensayo. Pero se trata también, y sobre todo, de una relación muy fértil, tanto en el plano de la teoría como en el de la práctica teatral.

$\mathrm{El}$ teatro siempre se ha nutrido de materiales narrativos. Todas las formas de relato -el mito, las crónicas, las leyendas, la historia, sagra- 
da y profana, la Biblia-, así como la literatura narrativa stricto sensu -poemas épicos, novelas, cuentos-, han proporcionado la materia prima, la sustancia argumental, la fábula, a la creación dramática, de la tragedia griega o los autos y misterios medievales, pasando por nuestro teatro del Siglo de Oro, Shakespeare, el drama romántico o Galdós, hasta Brecht, Buero, Miller, Anouilh, Sanchis Sinisterra o Mayorga. Sin embargo, en el teatro contemporáneo, o en buena parte de él, es fácil advertir a la vez una renuncia, o mejor, un rechazo al material narrativo, es decir, a «contar» historias o argumentos, a lo que llaman algunos dramaturgos en América «el cuentito» (Kartun: 2004). Basta pensar en Beckett, Ionesco, Pinter, Handke o Müller, o en El público de García Lorca, en Chéjov, etc.

En cuanto a lo que vagamente podemos llamar las formas narrativas, también puede notarse esa relación paradójica de asimilación y rechazo, de identidad y oposición, por parte del teatro. También desde esta perspectiva cabe encontrar lo narrativo en el origen del teatro mismo. Es por lo menos la visión que se desprende de la Poética aristotélica y su concepción evolutiva de los géneros, con la tragedia (el teatro) como culminación superadora de la epopeya (narrativa); también de la manera de presentar la evolución del propio género teatral como un progresivo aumento del número de actores. Se trataría, en definitiva, del proceso por el que una voz, en principio única, se va multiplicando o repartiendo entre distintas voces, cada vez más independientes y enfrentadas; del paso del monólogo al diálogo, en este sentido no etimológico de coloquio. Cuanto más nos remontamos al monólogo primigenio, más cerca nos encontramos seguramente de la narratividad. Cuanto más avanzamos en la polifonía, en el intercambio entre voces cada vez más autónomas, más patente se hace la genuina dramaticidad. Esquilo, Sófocles y Eurípides representan muy elocuentemente los tres estadios, inicial, central y final, de este proceso en la tragedia griega.

Tal proceso de diferenciación pone de manifiesto la oposición, muy nítida a mi modo de ver, que se establece entre las dos modalidades de la ficción, narrativa y dramática. Enseguida nos centraremos con detalle en ella. Por ahora valga simplemente como ejemplo la impresión de malestar que suele provocar la irrupción de discursos narrativos (por excesivos o mal integrados) en obras genuinamente dramáticas; lo que se siente como un estorbo, en menoscabo de la «puesta en acción» de los acontecimientos, que es lo que esperamos del teatro, de manera, por otra parte, intuitiva, sin que medie reflexión o teoría alguna sobre el particular, lo que revela lo hondamente sedimentada que se encuentra la oposición que estudiamos en nuestra cultura. 
Pero el proceso por el que narración y teatro se independizan distanciándose no resulta ser a la larga irreversible. Desde el ángulo que nos interesa, que es el del teatro, se producen en él recurrentes vueltas al monólogo o a acentuar su importancia relativa frente al diálogo -así en Séneca, por ejemplo-, lo que supone un regreso al origen, a Esquilo frente a Eurípides, y por tanto en alguna medida a lo narrativo. No deja de producir perplejidad que precisamente el teatro contemporáneo más reciente -no todo, pero sí una parte muy significativa de él- se caracterice por esa regresión a los orígenes o esa especie de primitivismo que supone la vuelta a Séneca y Esquilo, a una hegemonía del monólogo, a la contaminación con todas las formas de narratividad, extrema (Camino de Wolokolamsk, de Heiner Müller) o moderada (El sueño de Ginebra, de Juan Mayorga), adaptada (Sanchis Sinisterra) o no. ¿Por qué? ¿Será síntoma de una desconfianza en la forma dramática genuina, en el modo de representación propiamente teatral? ¿O será consecuencia de un ansia de originalidad en sentido etimológico, de refundación $a b$ initio? ¿Y tendrán algo que ver en ello razones mucho menos sublimes, casi exclusivamente alimenticias, como los costes de producción, mínimos si se trata del monólogo de un solo actor, y más aún si éste es de carácter narrativo, es decir, si todo el trabajo representativo corre a cargo de la palabra? ¿Y qué decir, tirando ya por lo bajo, del influjo de ciertos «formatos» televisivos o revisteriles, en la línea del contador de chistes más o menos hábilmente ensartados, influjo innegable al menos en el boom experimentado recientemente por el monólogo -no diré teatral- en los teatros?

Dejo en el aire estas preguntas, que subrayan que la relación que pretendo examinar aquí, por muy teórica que sea, y lo es mucho, no deja de tener implicaciones prácticas y de la más candente actualidad. Siendo mi propósito arrojar tanta luz como pueda sobre la mentada relación, no estará de más empezar por una aclaración terminológica, ya que los dos términos de referencia resultan ser particularmente polisémicos.

Con el término «narratividad» me refiero simplemente a los aspectos generales de lo narrativo, como los dos adelantados, formal y de material, además del que me parece más radical de todos y más útil por eso para plantear con la mayores garantías de claridad el asunto que nos ocupa -me refiero al concepto de «modo» aristotélico-; pero no a otras diversas acepciones más técnicas del término, como por ejemplo las recogidas en el Diccionario de teoría de la narrativa dirigido por Valles Calatrava (2002: 464-465); de las que conviene excluir expresamente la-digamosimperialista «de narratividad generalizada, como principio organizador de todo discurso (Greimas, 1986)» y cabría adoptar, en cambio, si fuera 
preciso, esta definición de Gerald Prince (1982): «el conjunto de propiedades que caracterizan a la narrativa y la distinguen de la no-narrativa, las características formales y contextuales que convierten a la narrativa en más o menos narrativa».

Por «teatro» entiendo, de acuerdo con mis propios intentos de definirlo (García Barrientos, 1981; 1991: 43-75; 1991b: 383-384), un tipo de espectáculo de actuación -no de escritura- que desarrolla una peculiar operación representativa. Se trata, como espectáculo, de un acontecimiento comunicativo cuyos productos son comunicados en el espacio y en el tiempo, es decir, en movimiento; que tiene lugar, en cuanto actuación, en una situación definida por la efectiva presencia en un mismo espacio y durante un mismo tiempo de actores y espectadores, sujetos del intercambio comunicativo; y que se basa en una convención representativa, específicamente teatral, que consiste en la «suposición de alteridad» que deben compartir los actores (por simulación) y el público (por denegación) y que dobla cada elemento representante en «otro» representado.

\section{Nudo}

Estoy convencido de que la categoría teórica fundamental -en el sentido fuerte del término- y la más útil para abordar la relación que nos ocupa con la máxima claridad y fecundidad sigue siendo todavía hoy, sin un ápice de exageración, por sorprendente que parezca, la distinción entre dos modos de imitación, es decir, de creación o representación de mundos imaginarios, que estableció Aristóteles en su Poética (48a1924): narrando lo imitado, «o bien presentando a todos los imitados como operantes y actuantes»; es decir, el modo narrativo y el modo dramático o teatral; o dicho de forma más expresiva, teniendo en cuenta lo desvaído u olvidado sin más que se encuentra ya el sentido etimológico de «drama», los modos de la narración y de la actuación. Este último es el modo de imitación propio de la tragedia y la comedia (es decir, del teatro), común a Sófocles y Aristófanes en cuanto imitadores, "pues ambos imitan personas que actúan y obran. De aquí viene, según algunos, que estos poemas se llamen dramas, porque imitan personas que obran» (48a28-30).

Sostengo que la visión -la teoría- de Aristóteles sobre los modos fue tan lúcida y penetrante que no ha perdido un ápice de su valor explicativo, es decir, que sigue siendo válida hoy (y ofrece, de paso, a los recalcitrantes detractores de la teoría literaria o artística, un excelente ejemplo 


\section{Teatro y narratividad}

de categoría genuinamente teórica, tal vez no indiferente a la historia o al paso del tiempo, pero sí con una vigencia de larga, de larguísima duración). Si tengo razón, el caso no puede ser más extraordinario. Resulta que, hace casi dos mil quinientos años, alguien -desde luego muy inteligente- señaló dos maneras de construir mundos de ficción, y ahí siguen, siendo dos y sólo dos, las mismas, hoy. Estar, como estoy, convencido de ello no implica negar que la teoría de los modos aristotélicos requiera una reformulación o hasta, si se quiere, una reintrerpretación; pero que no cabe apuntar aquí sino en forma axiomática y en extremo condensada (véase, con algo más de holgura, García Barrientos, 2004b: 17-22).

La clave, tanto de la vigencia de la oposición modal como de su reformulación haciendo explícito el principio más general en que basarla, puede encontrarse, por el camino más corto, confrontando los modos con el cine, un tipo de representación que Aristóteles -por muy listo que fuera- no podía prever. Hay que empezar por descartar que se trate de un tercer modo de imitación, totalmente nuevo. Su innegable parentesco tanto con lo dramático como con lo narrativo parece dejar claro que su novedad es más tecnológica que radical. Se impone entonces encuadrar el cine en alguno de los dos modos aristotélicos. La afinidad con el dramático es la más aparente. Pero lo que acerca el cine al teatro -su carácter espectacular- y lo aleja de la narración verbal, no depende a mi entender del modo de imitación, sino de los medios -verbales o espectaculares-con que se imita, por no salir de la terminología aristotélica. Lo que sí depende del modo y comparte el cine con la narración - de manera menos visible, claro- es el carácter mediado de la representación. La voz del narrador y el ojo de la cámara son, en cada caso, la instancia mediadora entre el mundo ficticio y el receptor; que sólo a través de esa intermediación tiene acceso al universo representado. La oposición modal puede, pues, ser reformulada en términos de representación in-mediata (la actuación, el drama) frente a representación mediata (la narración), con lo que el cine cae rotundamente del lado del modo narrativo.

Es a mi juicio en este nivel de abstracción, el de los modos, más alto que el de los «géneros» y, claro está, del suelo que ocupan las obras concretas y particulares, donde la oposición entre teatro y narración se da con la máxima pureza y claridad; y desde el que se puede examinar por tanto con las máximas garantías de despejar la sensación de confusión que se percibe a ras de suelo e incluso a la altura de los géneros. Por eso asombra que el Estagirita apenas preste atención, una vez alumbrada, a esta categoría teórica, tan luminosa y tan fértil, para centrarse enseguida en el estudio de los géneros. De forma que sólo a través de lo que dice de éstos -de la tragedia y de la epopeya- podemos extraer de la Poética 
algunas observaciones, implícitas, sobre los modos respectivos y la oposición entre ellos.

Tanto la tradición clasicista como en general el pensamiento teóricoliterario posterior siguen privilegiando el género sobre el modo, y siendo prácticamente mudos sobre éste último, el desarrollo de cuyas implicaciones es por eso escasísimo hasta fechas muy recientes. Hoy contamos, sin embargo, con sendas teorías del modo narrativo y del modo dramático de representación, para las que resulta germinal ese tan potente como relegado concepto aristotélico: una narratología expresamente modal como la de Gérard Genette (1972 y 1983) -quizás el fruto más depurado del paradigma formal-estructuralista-semiótico, el más fecundo sin duda del pensamiento literario del siglo XX- y una dramatología como la que -a falta de algo mejor (cf. Schaeffer, 1995: 620-621) - yo mismo estoy empeñado en construir, en paralelo y, sobre todo, en contraste con la anterior (García Barrientos, 1991, 2001, 2004). De ahí que esta última me parezca la disciplina idónea para estudiar la oposición entre dramaticidad y narratividad entendidas como modos, distintos, de crear mundos ficticios. Apuntaré a continuación, de forma necesariamente sumaria, algunos de los perfiles más visibles de ese contraste.

En primer lugar, aunque advierto una propensión generalizada a no verlas o reconocerlas, las diferencias en el plano textual son tan decisivas como evidentes a mi juicio. El modo in-mediato no determina menos la escritura dramática que la representación teatral. De entrada, imprime al texto dramático su peculiar estructura, radicalmente distinta a la del texto narrativo y que consiste en la superposición de dos «subtextos» nítidamente diferenciados, impermeables entre sí, que se van alternando, los que denominó Roman Ingarden (1931) Haupttext (texto principal) y Nebentext (texto secundario o complementario) y en español deberíamos convenir todos en llamar, de forma clara, sencilla y exacta, diálogo y acotación. Y, más decisivamente todavía, determina el carácter «objetivo» de la enunciación dramática, que comparten estos dos subtextos y que los diferencia de cualquier modalidad narrativa también radicalmente. Me refiero al estilo directo libre -es decir, no regido por «voz» superior alguna- del diálogo, y al lenguaje necesaria y radicalmente $\mathrm{im}$ personal -con exclusión de la primera (y segunda) persona gramaticalde la acotación.

Acierta Anne Ubersfeld (1977: 18) cuando afirma: «El primer rasgo distintivo de la escritura teatral es el no ser nunca subjetiva»; pero no, cuando, traicionando ese "nunca», considera al autor el «sujeto de la enunciación» de las acotaciones. Si, como dice antes (17), la clave está en preguntar quién habla en el texto de teatro, la respuesta es para mí clarí- 


\section{Teatro y narratividad}

sima: directamente cada personaje en el diálogo, y nadie -sí, nadie-en la acotación. Pues si realmente hablara el autor, o alguien, quien fuera, en las acotaciones, como cree ella y quizás la mayoría, ¿por qué no puede nunca decir «yo»? No me refiero, claro, a la mera posibilidad material de escribir acotaciones en primera persona, cosa que ha hecho, por ejemplo, José Luis Alonso de Santos en El álbum familiar, sino a que eso pueda resultar dramáticamente trascendente. Y es que el lenguaje de la auténtica acotación es, además de impersonal, mudo, no proferido, indecible, pura escritura sin posibilidad alguna de vocalización; en definitiva, como dijimos antes, enunciación sin sujeto. En eso radica la diferencia con algo que podría parecer semejante, la descripción en un texto narrativo; pero ésta, en cambio, es siempre proferida por una voz, la del narrador. Ni que decir tiene que el diálogo narrativo carece también de la inmediatez del dramático, pues siempre está en último término regido por esa misma voz (véase Bobes Naves, 1987: 136-141, y García Barrientos, 2001: 40$70)$.

En segundo lugar, puede resultar muy revelador del contraste entre los dos modos la simple comparación entre los «temarios» respectivos de la narratología y la dramatología, en particular de las que nos sirven como referencia (Genette, 1972 y García Barrientos, 2001: 28-242). Lo primero que llama la atención es que aparecen categorías comunes a las dos (tiempo, distancia, perspectiva y niveles representativos) y otras exclusivas de cada una. La principal categoría narratológica, en cuanto constituyente del mundo ficticio, capaz de integrar en sí misma a todas las demás, es la «voz» narrativa, con su núcleo en la figura del «narrador». Basta pensar que esa voz o esa figura es precisamente el instrumento de la mediación para entender que en el modo inmediato, en la actuación, su ausencia, o mejor su imposibilidad, es definitoria. En efecto, el drama puede definirse como el modo de construir un mundo de ficción sin voz alguna que lo constituya o como el relato sin narrador, en sentido estricto.

Hay dos categorías, en cambio, pertinentes para la dramatología y no para la narratología: el espacio y el personaje. Ambas son ingredientes esenciales, imprescindibles, de la representación teatral, a la vez representantes y representados, mientras que en la narrativa literaria forman parte sólo del contenido, o sea del universo representado. El espacio puede considerarse, como sugirió Jansen (1984, 1986: h-25 y ss.), la categoría dramática equivalente a la voz narrativa en cuanto uno y otra constituyen el «punto de acceso» al universo representado. El de una narración está constituido por todo lo que cuenta el narrador y sólo por lo que cuenta: para que cualquier elemento adquiera existencia narrativa es nece- 
sario y suficiente que pase por la voz del narrador, que sea nombrado por él. ¿Y para que un elemento tenga existencia «dramática», lo que para un personaje, por ejemplo, implica figurar en el reparto y ser encarnado por un actor en la representación? Creo que la condición es precisamente entrar en el espacio, o sea, ser visible, independientemente de su importancia, de que hable o no, etc. Ello a su vez implica una doble, en realidad triple, posibilidad de existencia, característica del teatro y vetada a la narración, los "grados de (re)presentación» que he llamado patente (Bernarda Alba, su bastón), latente (Pepe el Romano, el caballo garañón del tercer acto) y ausente (el marido de La Poncia, el mar); que constituyen una auténtica mina de los recursos o efectos más genuinos de la dramaturgia; y que son también consecuencia, me parece, de la inmediatez del modo de la actuación: de ahí que no pueda encontrarse nada igual en la narración literaria, ni siquiera en el cine.

Las categorías comunes a los dos modos también ponen de relieve con nitidez la oposición entre ellos. Desde el punto de vista más general, en lo que se refiere al tiempo, la inmediatez de la actuación reclama el presente; el pasado, en cambio, es el tiempo de la narración por su carácter mediado: contar algo implica que eso que se cuenta ha acontecido ya. Las posibilidades representativas del tiempo -excluyendo, claro, la pura significación lingüística de los diálogos- resultan más limitadas, aunque no tanto como se cree, en el teatro que en la narración literaria (y en el cine). La razón es que aquél cuenta con un tiempo real, representante-pragmático, del que éstos carecen: tiempo de la producción y la comunicación indiscernibles, que se traduce en una mayor coerción o rigidez del drama frente a una mayor libertad y flexibilidad de la narración para representar el tiempo.

El contraste es muy visible también en aspectos más particulares. Por ejemplo, en cuanto al orden, lo que es norma aplastante en la narración, las «anacronías» o quiebras del orden cronológico, la regresión y la anticipación, son, por el contrario, aunque posibles, rarísimas excepciones en el drama, y presentan en él, cuando se dan, un carácter objetivo casi brutal (aunque no se puedan justificar más que como producto de una subjetividad «mediadora», rigurosamente contradictoria con el modo de la actuación); mientras que en el modo narrativo su facilidad se sigue precisamente de la «mediatez» constitutiva: las regresiones son siempre en realidad retrospecciones subjetivas, y las anticipaciones, por fuerza, prospecciones o pre-visiones. Caso bien curioso es la imposibilidad de iteración propiamente dramática (no verbal), siendo así que el relato iterativo, es decir, que cuenta sintéticamente, de una vez, lo que se repite $n$ veces en el plano de la fábula o la historia, es ingrediente básico, difícil- 
mente prescindible, en cualquier narración literaria (y puede representarse también, en lo visual o espectacular, por medios genuinamente cinematográficos). Lo más cercano a la iteración que he podido encontrar en el teatro es la obra de Thornton Wilder The Long Christmas Dinner, que es un caso de drama en verdad "pseudo-iterativo» (cf. García Barrientos, 1991: 234-241).

No menos nítido se perfila el contraste modal en las tres categorías que integran lo que llamo la «visión» -es decir, la recepción-dramática; aunque poco más cabe aquí que remitir a la comparación expresa que hago de ellas en mi penúltimo libro (García Barrientos, 2001): «distancia narrativa y distancia dramática» (196-198), «perspectiva narrativa y perspectiva dramática» (210-215) y «niveles narrativos y niveles dramáticos» (230-232). Los niveles narrativos dependen radicalmente de la «voz» del narrador; los dramáticos, naturalmente, no: se encuadran, si se quiere, como las otras dos categorías, en lo que llama Genette el «modo» (en sentido restringido). De la distancia diré sólo lo significativo que resulta que en narrativa se hable de «efectos de realidad», pero no de distancia, y en el teatro de «efectos de distanciamiento» y no de ilusión de realidad. En lo que se refiere a la perspectiva, salta a la vista la perfecta adecuación de la narración y del cine a la expresión de la subjetividad, al acceso a la vida interior (pensamientos, sueños, imaginaciones o deseos no exteriorizados) y a los juegos con la focalización o el punto de vista, frente a la resistencia, que llega en ocasiones a la pura imposibilidad, que encuentran estos procedimientos en el modo de la actuación, en el teatro; lo que puede verificarse con pingües rendimientos en la pertinaz experimentación que llevó a cabo Buero Vallejo con la «perspectiva sensorial interna» a lo largo de toda su trayectoria dramática (cf. García Barrientos, 1985).

Confío en que estos ejemplos permitan vislumbrar que la oposición entre teatro y narratividad no sólo cuenta con una base sólida, bien fundada, sino que se perfila con la máxima pureza y claridad en el nivel de abstracción que representan los dos -y sólo dos- modos de imitación que ya distinguió Aristóteles: el de la narración y el del drama, o sea, el de la actuación.

\section{Desenlace}

Para hacer honor a la claridad invocada desde el principio, no debemos perder de vista que asomarnos ahora a las interferencias y contaminaciones entre teatro y narración implica ya descender a planos de 
mayor concreción: los que bajan desde los modos a los géneros (más o menos históricos) y desde éstos a las obras particulares. Aunque la cuestión no es menos antigua que moderna, como señalé antes, y no ha estado ausente de las polémicas y batallas literarias, incluso de alguna tan poco previsible al respecto como la del costumbrismo (cf. Ferraz Martínez, 2003), parece indiscutible que uno de los caminos más transitados por la dramaturgia contemporánea, desde finales del siglo XIX hasta hoy, ha sido el de una persistente y quizás progresiva narrativización. (También, aunque nos interese menos aquí, con el foco alumbrando el teatro, se ha dado cierta dramatización de la narrativa, por ejemplo en Valle-Inclán y en todas las manifestaciones del objetivismo: novela negra norteamericana, neorrealismo, nouveau roman, etc.; por cierto, con una clara implicación modal, pues se trata en todos los casos de reducir al mínimo las consecuencias de la mediación constitutiva). Me limitaré a hacer unas cuantas calas que permitan vislumbrar el asunto desde distintos ángulos.

En su Teoría del drama moderno (1880-1950), Peter Szondi (1956) estudió magistralmente la crisis que conoce la forma genuinamente dramática desde finales del siglo XIX (Ibsen, Chéjov, Strindberg, Maeterlinck, Hauptmann), con sus tentativas de preservación, en el naturalismo, el teatro conversacional, el acto único, la reclusión y el existencialismo, y sus tentativas de resolución, en la dramaturgia del yo del expresionismo, deudora del Stationendrama de Strindberg, la revista política de Piscator, el teatro épico de Brecht, el montaje escénico (Los criminales, de Bruckner), la función del drama imposible (Seis personajes en busca de autor, de Pirandello), el monólogo interior (Extraño interludio, de O’Neill), el yo épico como traspunte (Nuestro pueblo, de Thornton Wilder), el misterio sobre el tiempo (The Long Christmas Dinner, de Wilder) y el recuerdo (Muerte de un viajante, de Arthur Miller), que implican un cambio de estilo «debido a que el enunciado formal -estable e indiscutido- se verá puesto en entredicho por el contenido» (14). Szondi pretende explicar ese cambio histórico desde «una semántica propiamente dicha de la forma» (14), basada en la concepción dialéctica de Hegel acerca de la relación entre forma y contenido. Puede decirse, en términos muy generales, que el sentido de ese cambio consiste en un desplazamiento desde lo que él define como «drama» (17-22), un género histórico que viene a coincidir con la más genuina manifestación del modo dramático, hacia lo que entiende como su opuesto, lo «épico», que, en sus palabras, «recoge el rasgo estructural común a la epopeya, el relato, la novela y otros géneros, consistente en la presencia de lo que ha dado en designarse como «sujeto de la forma épica» o el «yo épico»» (16). 


\section{Teatro y narratividad}

Muy útil para el estudio de esta especie de contaminación del drama con lo narrativo en el siglo XX resulta el libro de Ángel Abuín (1997) El narrador en el teatro, centrado en -pero no limitado a- esta figura o recurso, y con un enfoque más formal o estructural, pero sin descuidar el contenido, sobre todo en los sustanciosos comentarios críticos de obras. Aunque vuelve, naturalmente, sobre autores tratados por Szondi, como Brecht, Wilder o Miller, la consideración se amplía, además de en el tiempo a la segunda mitad del XX, y al teatro Noh japonés, a autores como Paul Claudel (El zapato de raso, El libro de Cristóbal Colón), Tennessee Williams (El zoo de cristal), Alfonso Sastre (Ana Kleiber, Asalto nocturno, La taberna fantástica, Jenofa Juncal, la vieja gitana del monte Jaizkibel) o Antonio Buero Vallejo (La doble historia del doctor Valmy, El tragaluz, Caimán); y a muchas obras pertinentes para el asunto que nos ocupa, como, por ejemplo, La machine infernale de Jean Cocteau, Noche de guerra en el Museo del Prado de Rafael Alberti, El matrimonio del señor Missisippi de Dürrenmatt, Hölderlin de Peter Weiss, Judith contra Holofernes de Juan Antonio Hormigón, Jacques et son maître de Milan Kundera, La cinta dorada de María Manuela Reina, Descripción de un paisaje de Benet i Jornet, Miserere para medio fraile de Carlos Muñiz, etc. Basta leer el subtítulo del libro -La mediación como procedimiento en el discurso teatral del siglo $X X$ - o considerar que se abre con un capítulo (I: 13-21) titulado "Narratología y teatro» para advertir que toca muy de cerca el meollo de lo expuesto antes sobre los modos; aunque, a mi juicio, es al ámbito menos general de los géneros al que habría que referir sus consideraciones. Por eso quienes han visto en mi defensa de la pureza del modo dramático, como la del apartado anterior, un ataque a las tesis de Abuín, a quien tengo en muy alta estima y de quien me precio de ser amigo, no pueden andar más errados, seguramente porque no aciertan a comprender el concepto de «modo».

Precisamente porque me reconozco afectado de un considerable fundamentalismo teórico, por otra parte irremediable, soy partidario acérrimo de recorrer (también) el trayecto que va de las obras particulares y concretas hacia las categorías más generales y abstractas, como las de género y modo. A este procedimiento inductivo se ofrecen algunos casos privilegiados, como el de Pérez Galdós, con sus seis dramas derivados de otras tantas novelas propias. En un trabajo pionero, García Lorenzo (1970) compara muy detalladamente la novela y el drama titulados Doña Perfecta, centrándose en los cinco elementos que considera fundamentales para ambos géneros: la acción, los personajes, el tiempo, el espacio y el lenguaje. La conclusión en cada uno de los apartados apunta siempre a un proceso de simplificación, de selección y condensación, prescindien- 
do de lo accesorio en favor de lo esencial, al pasar de la novela al teatro. Muy lúcidamente apunta el enorme interés que encierra «el estudio de las novelas dialogadas o «habladas», según calificativo de Galdós, como puente entre la novela y el drama; [...] en ellas se puede observar una progresión, conscientemente realizada por Galdós, que va de Realidad, para el escritor todavía una novela, a El abuelo, obra ya más cerca de lo que debe ser teatro» (445-446). Precisamente en la comparación parcial de los dos textos de El abuelo, «un caso límite», como él mismo reconoce, basa el apartado «Texto épico-texto dramático» de su trabajo sobre géneros literarios Garrido Gallardo (1994: 135-139), con conclusiones que vale la pena tomar en consideración, como la de que «o no se puede hablar con rigor de diferencias entre diálogo novelesco y diálogo dramático, o hay que afirmar que estas novelas dialogadas no son tales novelas» (138). Más interesante, si cabe, es el caso, en cierto modo inverso, de ValleInclán. Bobes Naves (1985) confronta su drama Sacrilegio con dos partes de su novela La corte de los milagros en que aparecen los mismos personajes, los libros V («La jaula del Pájaro») y VII («Para que no cantes»), y llega a esta conclusión: «Los mismos presupuestos éticos y estéticos, los mismos personajes, las mismas acciones más o menos, la intención del autor de aproximar la novela a las formas dramáticas, no anulan totalmente las diferencias que los géneros literarios manifiestan en sus respectivos discursos» (72-73).

Muy interesante me parece, por último, el punto de vista de un dramaturgo -el más influyente quizás en la escena española actual- especialista en la teatralización de textos narrativos, que ha publicado recientemente sus reflexiones sobre esta experiencia, plasmada en más de dieciocho de esas adaptaciones, y concebida «como un proyecto de investigación, principalmente, de las fronteras entre narratividad y dramaticidad» en busca de "una teatralidad diferente, desafiada y cuestionada por el texto narrativo originario» (11). Me refiero a José Sanchis Sinisterra y su libro Dramaturgia de textos narrativos (2003), de carácter eminentemente didáctico: es transcripción de un seminario impartido en Villa de Leyva (Colombia) en agosto de 1996. Plantea la investigación en dos ámbitos, el de la relación entre narración oral y relato escrito, con vistas a la teatralización de este último, y el de la «disociación contextual» entre historia y discurso, que le lleva a distinguir una «dramaturgia historial» o "fabular» de una «dramaturgia discursiva», además de otra «mixta». De la primera, que no es el objeto preferente de su atención ni de su práctica dramatúrgica, y que es, para entendernos, la que aplica Galdós a sus novelas, interesa destacar la relación de las «propiedades de idoneidad de los relatos, con vistas a la dramaturgia histo- 


\section{Teatro y narratividad}

rial» (91-97), que son, elocuentemente, según él, éstas: la narración en tercera persona (que hace transparente o invisible el «discurso»), la estabilidad espacial, la continuidad (no dispersión) temporal, la concentración de personajes significativos y la abundancia de diálogos y monólogos.

Pero es el otro tipo el que interesa sobre todo a Sanchis: «¿No se podría hablar de una dramaturgia discursiva que procediera a operar sobre el discurso, del mismo modo que la dramaturgia fabular opera sobre la fábula? Esta inocente pregunta fue el punto de partida de todas mis investigaciones» (32). Se aduce también la justificación de que «en gran parte de los relatos contemporáneos, el discurso es lo esencial y la fábula, a veces, queda reducida a ser un mero pretexto narrativo» (59). Esta parte, que se desarrolla de forma práctica, mediante ejercicios de análisis de algunos textos narrativos con vistas a dramatizarlos, me parece lo más valioso del volumen. Aunque no resulte fácil generalizar, el procedimiento fundamental consiste en extraer la teatralidad del plano de la enunciación narrativa, analizando (o inventando) el plano de la «narración», según la terminología de Genette, plano que en el relato literario suele quedar significativamente «en suspenso», lo que lleva a repartir las voces del monólogo primordial entre varios locutores/personajes. Así, por ejemplo, en «Abogados» de Franz Kafka, «En el asilo» de Thomas Bernhard, etc.

En lo que se refiere al primer ámbito, señala el dramaturgo que «se suele olvidar que la tercera raíz de la teatralidad, junto al rito y la fiesta, es el relato oral» (27) y propone la distinción de tres niveles que van de la epicidad «pura» a la dramaticidad «plena»: $1^{\circ}$ ) «Epicidad pura» (2829) del texto narrado directamente al público por un único actor (en realidad, narrador); $2^{\circ}$ ) «Narradores múltiples» (29-30) que se hacen cargo en escena de la transmisión del relato: «Ahí comienza a aparecer una polifonía de la voz narrativa, que nos va aproximando a la dramaticidad» (29) pues los actores/narradores pueden asumir o repartirse ocasionalmente el papel de personajes; y $3^{\circ}$ ) «Narración dentro de la cuarta pared» (31), esto es, «en la que, en lugar de narrar al público, los actores-narradores se narran entre sí», nivel que permite, según Sanchis, "construir un ámbito dramatúrgico asombrosamente complejo y rico, una teatralidad fronteriza que está prácticamente por explorar» (31).

Dejando la práctica por la teoría, volviendo a los modos, para llegar a la conclusión, estos tres niveles, de no muy atinada denominación, vienen a confirmar a mi juicio la nitidez de la distinción modal. El primero es manifestación inequívoca del modo narrativo, aunque sin duda la más próxima al dramático y fronteriza con él. Es indiferente, me parece, que el ele- 
mento espectacular (vestido, gesto, accesorio, etc.) de la narración oral sea mínimo o máximo. De hecho, hay manifestaciones del modo narrativo mucho más espectaculares, como el cine, que no dejan por eso de ser «narraciones». El tercer nivel entra de lleno en el modo dramático; se trata de una narratividad discursiva plenamente integrada en él, es decir, dramatizada. Si lo entiendo bien, sería el resultado de extrapolar al drama entero las situaciones narrativas que, estrictamente delimitadas, como un quiste, han formado parte siempre de la estructura dramática, desde la tragedia griega y sus relatos de mensajero. Este nivel es, pues, limítrofe con el primero, cada uno a un lado de la línea divisoria, rectísima, que separa los dos modos. Es el nivel segundo de Sanchis el que parece presentar un carácter mixto, con participación de ambos modos, pues ofrece en efecto momentos puramente dramáticos alternando con otros genuinamente narrativos. Pero, en mi opinión, es rarísimo, si no imposible, amén de artificioso en extremo, que los dos ingredientes aparezcan escrupulosamente coordinados; lo normal es, por el contrario, que entren en relación de predomino del uno sobre el otro o de subordinación del otro al uno; de forma que el resultado es o una narración con incrustaciones dramáticas o un drama con interpolaciones narrativas, con lo que la pureza de la dicotomía modal vuelve a mostrarse sorprendentemente intacta.

Por fin, los criterios utilizados por Sanchis, el dirigirse directamente al público o la invocación a la «cuarta pared»son, a mi modo de ver, aunque pertinentes, efectos de algo más radical, la distinción entre narrador (verdadero) y personaje dramático (resultado del desdoblamiento impuesto por la convención teatral) o también entre las actividades verbales, radicalmente diferentes, de uno y de otros: el contar y el hablar. Las únicas voces que admite el drama son las de los personajes, que hablan pero no cuentan, o que, ocasionalmente, pueden sólo contar hablando. El genuino narrador literario, en cambio, cuenta casi siempre sin hablar, es decir, como si no tuviera la menor importancia el hecho de que deba estar hablando (o escribiendo) mientras cuenta. En suma, en el teatro el contar está siempre subordinado al hablar de los personajes y delimitado por él; en la narración el hablar de los personajes, y eventualmente del narrador, está siempre subordinado al contar de la voz narrativa y englobado en ese contar. Rotundamente, el genuino narrador es incompatible con el modo dramático; como el genuino personaje dramático, con sus dos caras, real y ficticia, es decir, un actor encarnando un papel, es incompatible con el modo narrativo, cine incluido. Si lo que vemos sobre un tablado son verdaderos personajes dramáticos, aquello será teatro; si es, en cambio, un narrador auténtico, o varios, aquello será una narración, oral y todo lo espectacular que se quiera, pero no un drama. Así de claro. 


\section{Teatro y narratividad}

\section{Bibliografía}

ABUín GonZÁLEz, Ángel (1997): El narrador en el teatro: La mediación como procedimiento en el discurso teatral del siglo XX, Santiago de Compostela, Universidade de Santiago de Compostela.

ARISTóteles, Poética, ed. trilingüe por Valentín García Yebra, Madrid, Gredos, 1974.

Bobes NAVES, $M^{\text {a }}$ del Carmen (1985): "Lengua y literatura en el texto dramático y en el texto narrativo", Estudios de semiología del teatro, Aceña / La Avispa, Valladolid / Madrid, 1988, pp. 48-73.

- (1987): Semiología de la obra dramática, Madrid, Taurus (2a ed. corregida y ampliada: Madrid, Arco Libros, 1997).

Ferraz Martínez, Antonio (2003): «Entre novela y teatro: El discurso de Mesonero Romanos sobre los artículos de costumbres en el marco de la transformación moderna del concepto de imitación", Revista de Literatura, LXV, 129, pp. 85-117

García BARrientos, José Luis (1981): "Escritura / Actuación: Para una teoría del teatro", Segismundo, 33-34, pp. 9-50 (También en M. C. Bobes Naves, comp., Teoría del teatro, Madrid, Arco Libros, 1997, pp. 253-294).

- (1985): «Punto de vista y teatralidad (El ejemplo de Buero Vallejo)», en M. A. Garrido Gallardo (ed.), Teoría semiótica: Lenguajes y textos hispánicos, Madrid, CSIC, pp. 627-635.

- (1991): Drama y tiempo: Dramatología I, Madrid, CSIC.

- (1991b): «Teatro, drama, texto dramático, obra dramática (Un deslinde epistemológico)», Revista de Literatura, LII, 106, pp. 371-390.

- (2001): Cómo se comenta una obra de teatro: Ensayo de método, Madrid, Síntesis, $2003^{2}$.

- (2004): Teatro y ficción: Ensayos de teoría, Madrid, Fundamentos.

- (2004b): “"Modos" aristotélicos y dramaturgia contemporánea», en L. M. Moncada (comp.), pp. 17-27.

GARCía LoREnZo, Luciano (1970): "Sobre la técnica dramática de Galdós: “Doña Perfecta». De la novela a la obra teatral", Cuadernos Hispanoamericanos, 250-51-52, Octubre 1970 a Enero 1971, pp. 445-471.

Garrido Gallardo, Miguel Ángel (1994): “Los géneros literarios: Teoría y análisis», La musa de la retórica, Madrid, CSIC, pp. 109-152.

GenetTe, Gerard (1972): «Discours du récit: Essai de méthode», Figures III, París, Seuil, pp. 62-282 (Trad. esp. de Carlos Manzano: Barcelona, Lumen, 1989).

- (1983): Nouveau discours du récit, París, Seuil (Trad. esp. de Marisa Rodríguez Tapia: Madrid, Cátedra, 1998).

Greimas, Algirdas-Julien y Joseph CourTès (1986): Semiótica: Diccionario razonado de la teoría del lenguaje II, Madrid, Gredos, 1991.

INGARDEN, Roman (1931): Das literarische Kunstwerk, Tubinga, Max Niemeyer, 1960 (Trad. esp. de Gerald Nyenhuis H.: México, Taurus / Universidad Iberoamericana, 1998).

JANSEN, Steen (1984): «Le rôle de l'espace scénique dans la lecture du texte dramatique: Quelques observations sur un "modèle" du genre dramatique et sur le Sei personaggi in cerca d'autore de Pirandello", en H. Schmid y A. Van Kesteren (eds.), Semiotics of drama and theatre: New perspectives in the theory of drama and theatre, Amstedam / Philadelphia, John Benjamins, pp. 254-289.

- (1986) : «Texte et fiction», Degrés, 46-47, pp. h-h34. 


\section{José Luis García Barrientos}

Kartun, Mauricio (2004): «El cuentito», en L. M. Moncada (comp.), pp. 31-35.

MoncadA, Luis Mario (comp.) (2004) Versus Aristóteles: Ensayos de dramaturgia contemporánea, México, Anónimo Drama Ediciones.

PRINCE, Gerald (1982): Narratology: The Form and Functionning of Narrative, Berlín, Mouton.

SANChis Sinisterra, José (2003): Dramaturgia de textos narrativos, Ciudad Real, Ñaque Editora.

SchAEFFER, Jean-Marie (1995): «Énonciation théâtrale», en O. Ducrot y J.-M. Schaeffer, Nouveau dictionnaire encyclopédique des sciences du langage, París, Seuil, s.v., pp. 612-621 (Ed. esp. dirigida por Marta Tordesillas: Madrid, Arrecife, 1998).

Szond, Peter (1956): Teoría del drama moderno (1880-1950), trad. de Javier Orduña, Barcelona, Destino, 1994.

UBERSFELD, Anne (1977): Semiótica teatral [Lire le théâtre], trad. y adaptación de Francisco Torres Monreal, Cátedra / Universidad de Murcia, 1989.

Valles Calatrava, José R. (dir.) (2002): Diccionario de teoría de la narrativa, Granada, Alhulia. 